\title{
ANTESEDEN dari ENTREPRENEURIAL INTENTIONS (NIAT BERWIRAUSAHA) pada MAHASISWA UNIVERSITAS AIRLANGGA (STUDI pada MAHASISWA ANGGOTA WEBS FAKULTAS EKONOMI dan BISNIS)
}

\author{
I Gusti Ngurah Widya Hadi Saputra \\ aUniversitas Pendidikan Nasional (Undiknas) Denpasar \\ ahadisaputra@undiknas.ac.id
}

\begin{abstract}
ABSTRAK
Jumlah lapangan kerja di Indonesia yang tidak sebanding dengan jumlah tenaga kerja yang ada menyebabkan tingginya tingkat pengangguran di Indonesia. Kondisi tersebut merupakan salah satu tantangan yang cukup besar yang harus dihadapi oleh Negara ini dalam rangka mengupayakan pembangunan Negara ke arah yang lebih baik. Pemerintah sudah sepantasnya meningkatkan upayanya dalam hal mengurangi pengangguran dengan menciptakan lapangan kerja baru atau dengan mendorong terciptanya wirausaha (entrepreneur).

Tujuan penelitian ini adalah untuk melihat pengaruh anteseden dari entrepreneurial intentions pada mahasiswa/i di Universitas Airlangga. Penelitian ini menggunakan metode survey terhadap 68 mahasiswa/i anggota WEBS di Fakultas Ekonomi dan Bisnis Universitas Airlangga dengan alat bantu statistik Partial Least Square (SmartPLS 2.0). Hasil penelitian menunjukkan bahwa hubungan antara individual skill terhadap attitude toward entrepreneurial behavior, perceived environmental dynamism terhadap perceived entrepreneurial behavior control, attitudes toward entrepreneurial behavior terhadap entrepreneurial intentions, dan subjective norms terhadap entrepreneurial intentions memiliki hasil yang positif dan signifikan; hubungan antara perceived environmental facility terhadap perceived entrepreneurial behavior control dan perceived entrepreneurial behavior control terhadap entrepreneurial intentions memiliki hasil yang positif namun tidak signifikan
\end{abstract}

Kata kunci : Entrepreneurial Intentions, Theory of Planned Behavior

\section{PENDAHULUAN}

Dewasa ini, jumlah lapangan kerja di Indonesia tidak sebanding dengan jumlah tenaga kerja yang ada. Hal inilah yang menyebabkan tingginya tingkat pengangguran di Indonesia. Kondisi tersebut merupakan salah satu tantangan yang cukup besar yang harus dihadapi oleh Negara ini dalam rangka mengupayakan pembangunan Negara ke arah yang lebih baik. Pemerintah sudah sepantasnya meningkatkan upayanya dalam hal mengurangi pengangguran dengan menciptakan lapangan kerja baru atau dengan mendorong terciptanya wirausaha (entrepreneur).

Kewirausahaan (entrepreneurship) adalah proses penciptaan dan mewujudkan nilainilai bagi pengusaha (Morris \& Jones, 1999). Kegiatan kewirausahaan memainkan peran cukup penting dalam meningkatkan pembangunan ekonomi dan sosial. Kewirausahaan dikenal untuk mengurangi tingkat pengangguran dan meningkatkan kesejahteraan masyarakat melalui penciptaan nilai dalam perekonomian. Suatu Negara dikatakan akan maju apabila memiliki paling sedikit 2 persen wirausaha dari total jumlah penduduk yang ada (www.hatta-rajasa.info). Namun situasi yang ada adalah Negara kita belum mampu mencapai jumlah ideal tersebut. 
Menjadi wirausaha sendiri dapat diartikan sebagai sebuah upaya yang dilakukan seseorang untuk menciptakan lapangan pekerjaan sendiri dengan membuka usaha atau menciptakan sesuatu yang baru. Seseorang telah meningkatkan perekonomian bagi dirinya sendiri maupun bagi orang lain di sekitarnya dengan berwirausaha. Hal tersebut tentunya memiliki arti dan kontribusi yang cukup besar baik bagi diri sendiri, orang sekitar, pemerintah, maupun Negara. Jika dari seorang entrepreneur berhasil mengurangi jumlah pengangguran minimal satu orang, maka apabila muncul entrepreneur lainnya tentu akan sangat bermanfaat dalam mengurangi pengangguran dengan maksimal. Keberadaan entrepreneur di negara ini semakin penting untuk direalisasikan. Melalui peningkatan entrepreneur, baik secara kuantitas maupun kualitas, mereka nantinya diharapkan menjadi katup pengaman untuk penciptaan kesempatan kerja, peningkatan produktivitas, dan peningkatan kesejahteraan masyarakat.

Pendidikan kewirausahaan belakangan kemudian menjadi salah satu alternatif upaya yang dilakukan oleh pemerintah guna menghadapi kenyataan tersebut. Baik di tingkat sekolah maupun perguruan tinggi, diberikan kurikulum atau bahan pendidikan terkait entrepreneurship. Banyak pula program-program di luar pendidikan formal seperti pelatihan entrepreneurship, seminar, workshop, dan lain sebagainya yang juga bertujuan untuk meningkatkan entrepreneurial intentions dan jumlah entrepreneur yang nantinya akan membantu dalam perbaikan pembangunan ekonomi Negara.

Program-program kewirausahaan yang diterapkan di universitas secara tidak langsung akan memunculkan wirausahawan muda di Indonesia. Program-program tersebut di program sedemikian rupa oleh Departemen Pendidikan Nasional dan Dikti melalui pemberian kurikulum dan melalui program kreativitas mahasiswa dengan tujuan untuk menciptakan lulusan perguruan tinggi yang siap bekerja dan menciptakan lapangan pekerjaan ketika lulus nanti. Salah satu universitas yang kemudian telah menerapkan dan mendukung program tersebut adalah Universitas Airlangga. Sebagai salah satu universitas terbaik di Indonesia, Universitas Airlangga telah mendukung kegiatan entrepreneurship melalui dukungan atas kegiatan mahasiswa yang memiliki bakat dan minat di bidang entrepreneur. Fakultas Ekonomi dan Bisnis, khususnya, memberikan dukungan terhadap program entrepreneurship melalui sebuah wadah unit kegiatan mahasiswa yang bernama WEBS. Melalui wadah inilah mahasiswa kemudian diberikan berbagai macam ilmu, mentoring, dan motivasi yang dapat menumbuhkan jiwa entrepreneurship mahasiswa.

Selain mengenai pemberian pendidikan kewirausahaan, cara lain yang ditempuh oleh pemerintah untuk mendorong semakin bertambahnya jumlah entrepreneur di Indonesia adalah dengan memberikan bantuan hibah modal usaha. Besarnya bantuan ini pun dapat dikategorikan cukup besar dan tentunya dengan memperoleh bantuan modal akan lebih memudahkan para entrepreneur muda untuk memulai bisnis atau usaha sendiri. Sebut saja dana bantuan hibah dari Kementrian UKM dan Koperasi yang tiap tahunnya menggelontorkan bantuan hingga $\mathrm{Rp} 25.000 .000$,- bagi setiap rintisan usaha untuk memotivasi semangat berwirausaha kaum muda di seluruh Indonesia (http://www.tempo.co/; http://www.depkop.go.id/). Selain dana bantuan modal dari pemerintah, jenis bantuan modal lainnya yang dapat diperoleh oleh para entrepreneur muda adalah melalui Kredit Usaha Rakyat (KUR) yang dapat mencapai Rp 500.000.000,- atau melalui program bina lingkungan hasil kerjasama dengan BUMN maupun perusahaan swasta lainnya yang memberikan bantuan corporate social responsibility (http://www.antaranews.com/).

Meskipun pemerintah telah mengeluarkan paket kebijakan seperti yang telah disebutkan diatas untuk mendorong kewirausahaan, perkembangan kewirausahaan di Indonesia bisa dibilang masih kurang dari harapan yang ingin dicapai oleh pemerintah. Mengapa hal ini bisa terjadi? Adanya berbagai hambatan yang dialami oleh para pengusaha atau entrepreneur di negara maju dan berkembang ketika memulai bisnis dan mengembangkan bisnis mereka (OECD, 2011) menjadi penyebab terjadinya hal tersebut. Memang tidak dapat dipungkiri, terdapat banyak faktor yang mempengaruhi niat atau intensi seseorang untuk berwirausaha disamping adanya hambatan yang dialami oleh individu tersebut. 
Dalam kaitannya di bidang entrepreneurship, intention models mengasumsikan bahwa perilaku kewirausahaan merupakan sebuah perilaku yang terencana, yang mencerminkan beberapa derajat pengolahan kognitif, dimana intentions tersebut berkembang dalam diri individu ketika ia mengelaborasikan pengetahuan, kepercayaan, sikap, dan pengalaman mereka (Krueger et al., 2000). Banyak model yang telah digunakan pada penelitian sebelumnya untuk menjelaskan dan mempelajari entrepreneurial intentions, namun yang paling secara umum digunakan adalah Theory of Planned Behavior (TPB). TPB (Ajzen, 1991) adalah salah satu kerangka teoritis yang dominan digunakan untuk menganalisis pembentukan niat di berbagai bidang (Armitage \& Conner, 2001), seperti bidang entrepreneurship. Terdapat tiga variabel sikap konseptual dalam TPB yang menjadi faktor dalam menentukan niat atau perilaku yaitu attitude towards the behavior, subjective norm, dan perceived behavioral control.

Untuk mengatasi permasalahan tersebut, kemudian dalam penelitian ini akan diteliti mengenai faktor-faktor yang terkait dengan pembentukan entrepreneurial intentions, utamanya kaum muda untuk menjadi entrepreneur. Hal ini karena kaum muda masih dalam tahap pencarian dan mereka juga belum menentukan secara pasti preferensi karir mereka ke depannya. Dalam penelitian ini yang menjadi responden adalah mahasiswa/i anggota WEBS di Fakultas Ekonomi dan Bisnis Universitas Airlangga. Pemilihan responden tersebut karena WEBS merupakan salah satu program unit kegiatan mahasiswa yang terdapat di lingkungan kampus Universitas Airlangga, khususnya di Fakultas Ekonomi dan Bisnis dan juga dalam program tersebut mahasiswa/i telah dibekali oleh pemahaman terkait entrepreneurship, sehingga dalam hal ini secara tidak langsung mereka telah memahami dan memiliki pandangan terkait entrepreneurship.

\section{KAJIAN LITERATUR}

\section{Entrepreneurship}

Kata kewirausahawan diambil dari istilah entrepreneurship yang berasal dari bahasa Perancis yaitu entre dan preneur yang berarti berusaha (Bird dan West, 1997). Selanjutnya definisi mengenai kewirausahaan atau entrepreneurship mulai banyak mengalami perkembangan.

Stevenson dan Jarillo (1990) mendefinisikan entrepreneurship sebagai berikut : entrepreneurship is about individuals who create opportunities where others do not, and who attempt to exploit those opportunities through various modes of organizing, without regard to resources currently controlled. Pendapat lain dari Barringer \& Ireland (2010) mendefinisikan entrepreneurship sebagai sebuah seni dalam mengubah ide menjadi sebuah bisnis.

Entrepreneurship merupakan kemampuan individu untuk mengunakan kesempatan melalui berbagai jalan. Entrepreneurship dapat juga diartikan sebagai suatu usaha untuk nilai kreasi melalui kesempatan bisnis, manajemen pengambilan risiko yang dari peluang yang ada dan melalui kemampuan komunikasi dan keahlian manajemen dalam menggerakkan manusia, keuangan dan sumberdaya materi untuk menghasilkan proyek dengan baik (Ranto, 2007).

Sedangkan entrepreneur merupakan seseorang yang mengambil risiko yang diperlukan untuk mengorganisasi dan mengelola suatu bisnis dan menerima imbalan atau balas jasa berupa keuntungan (profit) dalam bentuk finansial maupun non finansial. Seseorang yang mampu dan berani menciptakan lapangan kerja bagi diri sendiri dan orang lain, yang bertujuan mencari penghasilan untuk memenuhi kebutuhan hidup sendiri dan masyarakat pada umumnya.

Dengan demikian, dapat dirumuskan bahwa entrepreneur adalah orang yang mendirikan, mengembangkan, dan melembagakan usaha yang dimilikinya. Dalam usahanya itu dilakukan dengan penuh kreatif, inovatif, swa-kendali, dan siap mengambil resiko dalam melihat, 
menciptakan, dan memanfaatkan peluang untuk maju, dan meningkatkan usahanya (Riyanti, 2003).

\section{Entrepreneurial Intentions}

Menurut Ajzen (1991), intensi adalah anteseden langsung dari perilaku. Dinyatakan dalam tulisannya bahwa perilaku tidaklah dilakukan tanpa melalui proses berpikir, melainkan mengikuti suatu proses pemikiran yang melibatkan informasi relevan mengenai perilaku tersebut dan dapat diperkuat maupun diperlemah oleh peristiwa yang menyangkut perilaku tersebut.

Selanjutnya, Riyanti (2003) mengatakan bahwa intensi merupakan posisi seseorang dalam dimensi probabilitas subjektif yang melibatkan suatu hubungan antara dirinya dengan beberapa tindakan. Intensi merupakan faktor motivasional yang mempengaruhi tingkah laku. Intensi dipandang sebagai ubahan yang paling dekat dari individu untuk melakukan perilaku, maka dengan demikian intensi dapat dipandang sebagai hal yang khusus dari keyakinan yang obyeknya selalu individu dan atribusinya selalu perilaku.

Intensi memainkan peranan yang khas dalam mengarahkan tindakan, yakni menghubungkan antara pertimbangan yang mendalam yang diyakini dan diinginkan oleh seseorang dengan tindakan tertentu. Selanjutnya intensi adalah kesungguhan niat seseorang untuk melakukan perbuatan atau memunculkan suatu perilaku tertentu. Intensi mencerminkan kemauan yang kuat dari seseorang yang mengilhami dan memotivasi suatu perilaku tertentu. Peran intensi menentukan kualitas perilaku. Jika intensi seseorang yang tersebut kuat dan benar, maka akan mempengaruhi ketepatan dari perilaku, karena semua energi, material, dan informasi mendasari perilaku yang terjadi.

Entrepreneurial intentions didefinisikan sebagai kesediaan individu untuk melakukan perilaku kewirausahaan, untuk terlibat dalam tindakan entrepreneurship, menjadi entrepreneur, atau untuk membangun bisnis baru (Dell, 2008; Dhose \& Walter, 2010). Individu ingin menjadi entrepreneur karena mereka merasa bahwa entrepreneurship adalah jalur karir yang cocok bagi mereka (Davidsson, 1995). Mereka juga merasa bahwa dengan menjadi entrepreneur, mereka dapat mencapai tujuan pribadi mereka, mengejar ide-ide mereka, dan mencapai financial rewards (Barringer \& Ireland, 2010).

Entrepreneurial intentions dapat diartikan juga sebagai niat atau keinginan yang ada pada diri seseorang untuk melakukan suatu tindakan entrepreneurship (Wijaya, 2007). Para ahli telah membuktikan bahwa entrepreneurial intentions merupakan prediktor yang valid untuk perilaku entrepreneurship dimana tindakan entrepreneurship dimasukkan ke dalam kategori perilaku yang disengaja. Dengan mempelajari entrepreneurial intentions akan memberikan wawasan bagi peneliti untuk memahami proses kewirausahaan dan dapat memprediksi kegiatan kewirausahaan dengan cara yang lebih baik dengan mengidentifikasi faktor anteseden dari entrepreneurial intentions.

Menurut Bird (1988), intensi adalah keadaan pikiran yang mengarahkan perhatian dan tindakan seseorang terhadap suatu objek tertentu (tujuan) atau jalan untuk mencapai sesuatu . Intensi juga merupakan motivasi seseorang untuk merencanakan atau membuat keputusan. Bird (1988) selanjutnya menyatakan bahwa entrepreneurial intentions mengacu pada keadaan pikiran individu yang ditujukan untuk menciptakan usaha baru, mengembangkan konsep bisnis baru atau menciptakan nilai baru dalam perusahaan. Hal tersebut merupakan faktor penting dalam memfasilitasi pembentukan usaha baru dan memiliki dampak yang signifikan terhadap kesuksesan, kelangsungan hidup dan pertumbuhan bisnis. Dalam mengukur entrepreneurial intentions dapat dilakukan dengan mengajukan pertanyaanpertanyaan seperti berikut : "apakah anda akan memulai sebuah usaha?" (mengukur keinginan), "apa yang akan Anda pilih, bekerja untuk diri sendiri atau bekerja untuk orang lain" (mengukur preferensi), "apakah anda berencana untuk memulai bisnis "(tentang perencanaan)," Seberapa besar kemungkinan bahwa Anda akan memulai bisnis dalam 5 tahun ke depan "(perilaku yang diharapkan) (Van Gelderen et al., 2008). 


\section{Theory of Planned Behavior}

Theory of Planned Behavior (Ajzen, 1991) adalah salah satu kerangka teoritis yang dominan digunakan untuk menganalisis pembentukan niat di berbagai bidang (Armitage \& Conner, 2001). Theory of Planned Behavior adalah teori mengenai hubungan antara keyakinan dan perilaku. Teori ini telah diterapkan untuk studi tentang hubungan antara keyakinan, sikap, niat perilaku dan perilaku dalam berbagai bidang seperti advertising, public relations, advertising campaign dan healthcare.

Dalam TPB disebutkan bahwa secara konseptual terdapat tiga variabel sikap yang menentukan niat atau intensi yaitu : attitude towards the behavior, subjective norm, dan perceived behavioral control. Attitudes mengacu pada sejauh mana individu mengevaluasi suatu perilaku spesifik apakah perilaku tersebut menguntungkan atau tidak menguntungkan (Ajzen, 1988). Subjective norm mencerminkan tekanan sosial yang dirasakan oleh individu yang berasal dari figur-figur tertentu untuk melakukan atau tidak melakukan suatu perilaku tertentu (Ajzen, 1988). Perceived behavioral control mengandung persepsi terkait kemampuan untuk berhasil melaksanakan dan mengontrol perilaku fokal (Ajzen, 1991, 2002). Secara umum, semakin baik attitudes dan subjective norms seseorang berkaitan dengan perilaku dan semakin besar perceived behavioral control atas perilaku tersebut, maka niat individu untuk melakukan perilaku fokal tersebut akan semakin kuat (Armitage \& Conner, 2001).

\section{Attitude toward Entrepreneurial Behavior}

Eagly \& Chaiken (1993) menyatakan bahwa sikap (attitudes) adalah kecenderungan psikologis pihak tertentu yang memiliki sifat-sifat evaluatif, baik yang menguntungkan atau tidak, terhadap perilaku tertentu, yang meliputi aspek kognitif, aspek afektif, dan aspek konatif. Menurut Ajzen dan Fishbein (1977), sikap dan perilaku saling berhubungan. Mereka berpendapat bahwa perilaku secara sistematis didahului oleh keputusan untuk bertindak, dimana sikap berkontribusi untuk membentuk perilaku masa depan seperti yang telah direncanakan secara kognitif. Namun, hubungan antara sikap dan perilaku tidaklah linear atau searah, "sikap mempengaruhi perilaku dan perilaku mempengaruhi sikap" (Brannback et al., 2007). Dalam rangka untuk mengungkapkan suatu perilaku, sikap pertama kali diperlukan untuk menghasilkan "niat". Davidson dan Jaccard (1979) menunjukkan bahwa ada hubungan positif yang kuat antara niat dan perilaku. Bagozzi (1981) secara empiris menunjukkan bahwa sikap mempengaruhi perilaku melalui dampak adanya niat perilaku. Dengan demikian, niat ditekankan sebagai prediktor terbaik dari perilaku yang direncanakan, termasuk dalam hal entrepreneurship (Krueger et al., 2000). Terkait dalam hal entrepreneurship, attitudes toward entrepreneurial behavior mengukur tentang ekspektasi individu terkait tindakan memulai bisnis baru.

\section{Individual Skill}

Faktor lainnya yang kemudian juga menjadi faktor munculnya entrepreneurial intentions seseorang adalah individual skill yang dimilikinya. Wiklund dan Shepherd (2003) berpendapat bahwa baik niat dan perilaku kewirausahaan dapat dikonseptualisasikan sebagai fungsi dari kemampuan pribadi entrepreneur. Skill dan pengetahuan yang dimiliki oleh individu merupakan suatu konsep multidimensi. Para ahli telah mengidentifikasi beberapa dimensi yang mungkin berguna untuk mengkarakterisasi hal tersebut, seperti misalnya technical, procedural, dan managerial skill (Baum et al., 2001), patenting (Roberts, 1991), dan serial entrepreneurship (Kolvereid, 1996).

Beberapa ahli lain juga berpendapat bahwa skill dan kompetensi berperan dalam penentuan sikap seseorang. Kolvereid (1996) menyebutkan bahwa sikap (attitudes) memediasi hubungan antara skill dan entrepreneurial intentions. Hal ini sejalan dengan asumsi oleh Ajzen dan Fishbein (1980) yang berpendapat bahwa kompetensi memiliki dampak tidak langsung pada niat atau intensi tertentu, dengan mempengaruhi beberapa faktor yang berkaitan dengan hal tersebut (seperti misalnya sikap atau attitudes). Shapero dan Sokol (1982), serta Souitaris, 
Zerbinati, dan Al-Laham (2007) memperkuat alasan di atas, dengan menyatakan bahwa skill individu berpengaruh langsung pada attitudes dan berpengaruh tidak langsung pada intensi.

\section{Subjective Norms}

Nilsson, Borgstede, \& Biel (2004) menegaskan bahwa subjective norms merupakan konstruk yang menjelaskan keyakinan seseorang yang merujuk pada pengaruh pihak lain dalam berperilaku dengan cara tertentu dan yang menjadi motivasi untuk memenuhi referensi tertentu. Dengan kata lain, subjective norms adalah kecenderungan seseorang untuk mempertimbangkan dan mengikuti pandangan, bimbingan, dan dorongan untuk berperilaku atau tidak berperilaku dari pihak lain baik itu dari individu maupun kelompok, seperti dari kerabat, teman, dan tokoh masyarakat. Sementara itu, menurut Rhodez \& Courneya (2003), subjective norms mencerminkan penilaian dari tekanan sosial pada seseorang untuk berperilaku atau tidak berperilaku, termasuk dalam entrepreneurial behavior. Dalam menentukan pilihan untuk terjun menekuni entrepreneurship, pendapat orang tua atau teman dan lain-lain yang signifikan mungkin penting bagi seseorang karena ia mungkin masih dalam tahap mengeksplorasi pilihan karir yang akan ditempuh.

\section{Perceived Entrepreneurial Behavior Control}

Ajzen (2005) menyatakan bahwa behavioral control menjelaskan persepsi seseorang terhadap beberapa faktor yang memberikan kemudahan dan kesulitan dalam aktualisasi perilaku tertentu. Behavioral control mengukur kemampuan seseorang untuk mengontrol perilaku yang diarahkan sampai pada hasil yang diharapkan dari perilaku tersebut.

Behavioral control didasarkan pada seberapa jauh seseorang bersedia dan mampu mengendalikan perilakunya, sehingga kecenderungan perilakunya dapat diamati, apakah perilaku tersebut memberikan kemudahan atau kesulitan. Jika behavioral contro/nya tinggi, maka hal tersebut akan memberikan kesempatan yang lebih baik dimana : individu tersebut akan lebih siap, lebih optimis, lebih mudah, dan mampu menguasai proses untuk memulai dan mengembangkan entrepreneurship dan begitu pula sebaliknya. Franke dan Luthje (2004) juga mengungkapkan bahwa niat seseorang untuk berwirausaha dipengaruhi langsung oleh persepsi terhadap peluang dan rintangan kewirausahaan. Secara khusus, semakin positif seseorang merasakan dukungan untuk kewirausahaan, semakin kuat niat kewirausahaan mereka.

\section{Perceived Environmental Facility}

Ketika membahas domain entrepreneurship, dalam beberapa literatur dinyatakan bahwa faktor lingkungan eksternal sangatlah penting dalam mendukung aktivitas kewirausahaan (Fini, Grimaldi, \& Sobrero, 2009), diantaranya adalah dukungan dari sektor pemerintah maupun dari lingkungan pendidikan atau universitas.

Para ahli telah menekankan bahwa kebijakan pemerintah, karakteristik konteks lokal (misalnya ketersediaan infrastruktur logistik, investor keuangan, dan eksternalitas) serta mekanisme dukungan universitas mempengaruhi kegiatan kewirausahaan (Morris \& Lewis, 1995;. Fini et al., 2009). Dukungan yang dapat dilakukan oleh pemerintah salah satunya dengan melakukan intervensi dengan skema pendanaan, kebijakan pajak, dan mekanisme pendukung lainnya yang ditujukan untuk mengurangi inefisiensi pasar dan mempromosikan kewirausahaan (Lerner, 1999). Sementara penelitian lain terkait konteks lokal menyebutkan bahwa dengan adanya lingkungan yang subur atau kaya, baik itu dari sisi sumberdaya fisik maupun nonfisik mampu meningkatkan niat kewirausahaan (Niosi \& Bas, 2001). Secara khusus disebutkan juga bahwa dukungan finansial, seperti ketersediaan modal ventura (Beck, Demirguc-Kunt, \& Maksimovic, 2005), serta layanan dukungan kewirausahaan, seperti kesempatan pelatihan, kredit kecil, infrastruktur fisik, dan kompetisi rencana bisnis (Feldman, 2001; Foo, Wong, \& Ong, 2005), telah diidentifikasi sebagai faktor utama dalam mendukung kewirausahaan. 
Selain dukungan dari pemerintah, dukungan dari universitas juga menjadi salah satu faktor munculnya niat kewirausahaan mahasiswa. Para ahli berpendapat bahwa mekanisme dukungan tertentu yang dilalukan oleh universitas juga relevan dalam mendorong kegiatan transfer teknologi dan pengetahuan, yang kemudian mendukung tindakan kewirausahaan. Himpunan kebijakan dan instrumen yang telah diberlakukan oleh universitas dalam rangka mendukung kewirausahaan cukup bervariasi, antara lain termasuk bantuan konsultasi, transfer teknologi dan pengetahuan (Mian, 1996), tersedianya university incubator maupun sumber daya atau fasilitas fisik lainnya (Mian, 1997), serta dana ventura dari universitas (Lerner, 2005).

\section{Perceived Environmental Dynamism}

Selain hal-hal yang telah disebutkan di atas, faktor lingkungan lainnya yang mempengaruhi entrepreneurial intentions adalah dinamisme lingkungan. Hal ini berkaitan juga dengan inovasi yang dimiliki seseorang dalam memandang kesempatan maupun peluang yang ada di pasar maupun lingkungannya.

Karakteristik industri yang heterogen dengan banyaknya peluang yang ada akan memicu niat kewirausahaan seseorang. Semakin dinamis dan kompetitif lingkungan tersebut, maka semakin besar pula kebutuhan untuk inovasi dan semakin besar juga kemungkinan bahwa seseorang akan menjadi inovatif (Meyers \& Marquis, 1969). Heterogenitas pasar ini kemudian mempengaruhi keragaman organisasi (baik itu personel, prosedur, teknologi, dan praktik administrasi), dan semakin besar keragaman ini maka semakin besar kemungkinan munculnya ide-ide inovatif baru dan meningkatkan niat kewirausahaan (Miller \& Friesen, 1982).

Tidak dapat dipungkiri bahwa lingkungan yang dinamis dan heterogen ini akan memunculkan inovasi, sikap proaktif, dan risk-taking behavior seperti entrepreneurial behaviors (Covin \& Slevin, 1989; Miller \& Friesen, 1982). Para ahli juga berpendapat bahwa tanpa adanya heterogenitas pasar maka tidak akan muncul ruang untuk entrepreneurship (Sakarya, Eckman, \& Hyllegard, 2007), dan sebagai konsekuensinya akan semakin sedikit pula peluang maupun kesempatan bagi seseorang untuk terpengaruh dan memiliki kontrol terhadap entrepreneurial behavior mereka.

Dari kajian literatur di atas, kemudian ditarik hipotesis penelitian sebagai berikut :

\section{Direct Antecedents dari Entrepreneurial Intentions}

Anteseden pertama adalah attitude toward entrepreneurial behavior. Attitudes merupakan apa yang kita rasakan terhadap suatu konsep (objek dari sikap), berupa orang, merk, idiologi, ataupun entitas lain yang melampirkan perasaan. Dengan kata lain, attitude merupakan evaluasi (baik atau buruk) yang kita berikan untuk suatu konsep tertentu. Attitude berkembang dari keyakinan seseorang terhadap obyek suatu sikap. Secara umum, keyakinan dibentuk dengan mengaitkannya dengan suatu atribut atau karakteristik tertentu. Dalam kaitannya pada attitude toward entrepreneurial behavior, masing-masing keyakinan berhubungan dengan suatu tindakan atau perilaku. Dari penilaian baik atau buruknya suatu tindakan, kita kemudian akan mengetahui sejauh mana attitude toward behavior, dimana ketika seseorang merasa bahwa suatu perilaku menguntungkan baginya, hal tersebut kemudian diterjemahkan ke dalam niat yang kuat untuk melaksanakan perilaku yang diinginkan.

Anteseden kedua mengacu pada subjective norms, terkait persepsi seorang entrepreneur pada persetujuan atau rujukan dari sosok individu (atau kelompok) yang penting baginya dalam kaitannya dengan keterlibatan mereka dalam penciptaan nilai baru melalui tindakan inovatif, proaktif, dan berisiko. Jika attitude menggambarkan faktor pribadi yang mempengaruhi kemungkinan seseorang dan keinginannya untuk terlibat dalam perilaku tertentu, subjective norms menggambarkan faktor-faktor sosial yang mempengaruhi individu. Dengan kata lain, norma subjektif adalah tekanan sosial yang dirasakan dan dihadapi seseorang ketika akan memutuskan apakah akan mengambil suatu tindakan atau perilaku dengan cara tertentu. 
Anteseden ketiga adalah perceived entrepreneurial behavior control, yaitu keyakinan individu yang berkaitan dengan betapa mudahnya bagi mereka untuk menciptakan suatu nilai melalui keterlibatannya dalam tindakan inovatif, berisiko, dan proaktif. Perilaku seseorang pada umumnya sangat dipengaruhi oleh kepercayaan diri mereka pada kemampuan mereka untuk melakukan sesuatu. Perceived behavioral control berkembang dari kontrol keyakinan seseorang tentang ada atau tidak adanya sumber daya yang diperlukan dan peluang. Kontrol keyakinan mungkin didasarkan sebagian pada pengalaman masa lalu, tetapi mereka juga biasanya akan dipengaruhi oleh second-hand information tentang perilaku, dengan pengalaman kenalan dan teman-teman, dan dengan faktor-faktor lain yang meningkatkan atau mengurangi kesulitan yang dirasakan terkait melakukan perilaku yang bersangkutan. Semakin banyak dukungan yang didapat dan semakin kecil hambatan yang dirasakan, maka semakin besar kontrol seseorang atas entrepreneurial behavior.

Hasil teoritis dan empiris dalam psikologi dan sosiologi secara luas mengkonfirmasi bahwa attitudes, subjective norms, dan perceived behavioral control memiliki kemampuan untuk memprediksi niat (Armitage \& Conner, 2001). TPB juga telah menerima dukungan yang kuat dalam domain manajemen dan kewirausahaan, dimana banyak kontribusi berhasil menunjukkan validitas prediktif dari teori tersebut dalam menjelaskan niat ke arah kewirausahaan (Kolvereid, 1996; Krueger et al., 2000; Luthje \& Franke, 2003). Dari penjelasan di atas, dapat ditarik hipotesis sebagai berikut :

$\mathrm{H} 3 \mathrm{a}$ : attitudes toward entrepreneurial behavior berpengaruh signifikan positif terhadap entrepreneurial intentions seseorang.

$\mathrm{H} 3 \mathrm{~b}$ : subjective norms berpengaruh signifikan positif terhadap entrepreneurial intentions seseorang.

$\mathrm{H} 3 \mathrm{c}$ : perceived entrepreneurial behavior control berpengaruh signifikan positif terhadap entrepreneurial intentions seseorang.

\section{Indirect Antecedents dari Entrepreneurial Intentions \\ Anteseden dari Attitude toward Entrepreneurial Behavior : "Inner" Domains}

Individual skill. Attitudes dapat diprediksi melalui faktor kognitif seperti skill dan abilities (Locke, 2000). Hal ini sejalan dengan asumsi oleh Ajzen dan Fishbein (1980) yang menyebutkan bahwa kompetensi hanya berpengaruh secara tidak langsung pada intensi, dengan mempengaruhi faktor-faktor yang berhubungan dekat dengan intensi tersebut (seperti misalnya attitudes). Sejalan pula dengan TPB, kesadaran seseorang pada skill dan kompetensinya tidak langsung menentukan niat tapi memberikan pengaruh pada tingkat sejauh mana seseorang mengembangkan penilaian (menguntungkan atau tidak) terkait perilaku yg bersangkutan. Oleh karena itu, adanya kesadaran tentang kompetensi memberikan evaluasi yang lebih baik untuk fokus perilaku yang dituju, yang secara tidak langsung mendorong munculnya niat. Kolvereid (1996) menunjukkan bahwa attitudes memediasi hubungan antara skill dan entrepreneurial intentions. Selain itu, Shapero dan Sokol (1982), serta Souitaris, Zerbinati, dan Al-Laham (2007), juga memperkuat hal tersebut, dimana individual skill berpengaruh secara langsung pada attitudes dan berpengaruh tidak langsung pada entrepreneurial intentions. Maka dari penjelasan tersebut kemudian ditarik hipotesis sebagai berikut :

$\mathrm{H} 1$ : individual skill seseorang berpengaruh signifikan positif terhadap attitude toward entrepreneurial behaviomya.

\section{Anteseden dari Perceived Entrepreneurial Behavior Control : "Outer” Domains}

Perceived Environmental Facility. Ketika masuk domain entrepreneurship, beberapa literatur menggambarkan pentingnya dukungan lingkungan eksternal untuk mendukung kegiatan kewirausahaan (Fini, Grimaldi, \& Sobrero, 2009). Hal-hal seperti dukungan pemerintah, status ekonomi, ketersediaan modal, infrastruktur, layanan dukungan kewirausahaan mampu mendukung dan mempromosikan kegiatan kewirausahaan. Selain itu, dukungan universitas 
juga menjadi pemicu munculnya entrepreneurial behavior seseorang, utamanya mahasiswa/i. Dengan adanya lingkungan yang mendukung, maka akan berpengaruh positif pada kendali seseorang untuk melaksanakan perilaku kewirausahaan, dan mempengaruhi rasa percaya diri mereka untuk berhasil ketika menerapkan perilaku kewirausahaan.

Perceived Environmental Dynamism. Selain keberadaan sumberdaya seperti yang telah disebutkan di atas, adanya peluang juga mempengaruhi niat dan tindakan seseorang. Semakin besar jumlah peluang yang dirasakan seseorang, maka semakin besar pula kontrol atas perilaku fokal (Ajzen, 1991). Lingkungan yang dinamis dan berubah-ubah, memungkinkan individu untuk lebih memahami, menemukan, atau menciptakan peluang. Selain itu, lingkungan yang aktif dan heterogen akan mengasah perilaku inovatif, proaktif, dan keberanian individu untuk mengambil resiko. Dari penjelasan tersebut dapat ditarik hipotesis sebagai berikut :

$\mathrm{H} 2 \mathrm{a}$ : Perceived environmental facility berpengaruh signifikan positif terhadap perceived entrepreneurial behavior control seseorang.

$\mathrm{H} 2 \mathrm{~b}$ : Perceived environmental dynamism berpengaruh signifikan positif terhadap perceived entrepreneurial behavior control seseorang.

\section{METODE}

Penelitian ini menggunakan alat uji statistik untuk menjawab rumusan masalah dan menguji hipotesis yang telah dbuat berdasarkan kajian teori serta penelitian terdahulu. Secara spesifik penelitian ini menggunakan Partial Least Square (PLS). Penelitian ini menggunakan skala Likert 1 sampai dengan 5 untuk mengukur variabel.

Populasi dari penelitian ini adalah seluruh mahasiswa/i anggota WEBS yang berjumlah 68 orang. Populasi ini dipilih karena dalam program tersebut, mahasiswa/i telah dibekali oleh pemahaman terkait entrepreneurship, sehingga dalam hal ini secara tidak langsung mereka telah memahami dan memiliki pandangan terkait entrepreneurship. Sampel yang digunakan dalam penelitian ini merupakan sampling jenuh atau dikenal juga dengan sensus dimana seluruh populasi digunakan sebagai sampel. Jumlah sampel dalam penelitian ini adalah 68 orang mahasiswa/i yang tergabung di WEBS Fakultas Ekonomi dan Bisnis Universitas Airlangga.

\section{HASIL DAN PEMBAHASAN}

Data penelitian ini diperoleh dari penyebaran kuisioner kepada sampel/responden penelitian. Kuisioner yang disebarkan sebanyak 68 kuisioner dan seluruh kuisioner tersebut dapat digunakan dalam penelitian ini. kuisioner disebarkan pada responden yaitu mahasiswa/l Fakultas Ekonomi dan Bisnis Universitas Airlangga yang merupakan anggota dari WEBS (Workshop Entrepreneur Business Society).

Dari hasil uji analisis dengan Smart PLS, terdapat beberapa indikator yang dihilangkan (ATT1, ATT2, ATT5, ATT6, GS1, PEBC2, PEBC5, SN1, US1, US2, dan US4) karena tidak memenuhi persyaratan uji validitas konvergen.

Setelah mengetahui validitas dan reliabilitas item kuesioner dan mengetahui goodness-fit mode/ yang dihasilkan dari analisis Smart PLS dan hasil uji koefisiensi parameter jalur, Peneliti akan melakukan pengujian hipotesis yang telah disusun sebelumnya. Pengujian hipotesis dilakukan dengan melihat besarnya nilai t-statistic. Hipotesis dikatakan diterima apabila nilai $t$-statistic dari hipotesis yang diajukan memiliki nilai lebih dari 1,96 untuk signifikansi 5 persen dan lebih dari 1,64 untuk signifikansi 10 persen. Namun apabila tidak memenuhi syarat tersebut maka dapat dikatakan hipotesis yang ada tersebut ditolak. Nilai $t-$ statistic dapat dilihap pada tabel path coefficient ( $T$-statistic) pada tabel 1 berikut ini. 


\section{Tabel 1}

Nilai Path Coefficients

\begin{tabular}{|l|c|c|c|c|c|}
\hline & $\begin{array}{c}\text { Original } \\
\text { Sample } \\
(\mathbf{O})\end{array}$ & $\begin{array}{c}\text { Sample } \\
\text { Mean (M) }\end{array}$ & $\begin{array}{c}\text { Standard } \\
\text { Deviation } \\
\text { (STDEV) }\end{array}$ & $\begin{array}{c}\text { Standard } \\
\text { Error } \\
\text { (STERR) }\end{array}$ & $\begin{array}{c}\text { T Statistics } \\
(\text { (IO/STERR|) }\end{array}$ \\
\hline ATT -> EI & 0.2745 & 0.2743 & 0.0865 & 0.0865 & 3.1743 \\
\hline ISI -> ATT & 0.3538 & 0.3526 & 0.1341 & 0.1341 & 2.6378 \\
\hline PEBC -> EI & 0.0032 & -0.0092 & 0.1252 & 0.1252 & 0.0254 \\
\hline PED -> PEBC & 0.3711 & 0.3949 & 0.1009 & 0.1009 & 3.6776 \\
\hline PES -> PEBC & 0.1592 & 0.1727 & 0.1063 & 0.1063 & 1.498 \\
\hline SN -> EI & 0.503 & 0.5107 & 0.0943 & 0.0943 & 5.3357 \\
\hline
\end{tabular}

Tabel 1 menunjukan bahwa hasil uji hipotesis memiliki empat hipotesis diterima dari enam hipotesis. Hipotesis ini diterima dikarenakan nilai T-statistics $>1.96$ Empat hipotesis dari enam hipotesis yakni individual skill berpengaruh signifikan positif terhadap attitude toward entrepreneurial behavior; perceived environmental dynamism berpengaruh signifikan positif terhadap perceived entrepreneurial behavior control; attitudes toward entrepreneurial behavior berpengaruh signifikan positif terhadap entrepreneurial intention; dan subjective norms berpengaruh signifikan positif terhadap entrepreneurial intentions. Adapun hipotesis yang ditolak adalah perceived environmental facility berpengaruh signifikan positif terhadap perceived entrepreneurial behavior control dan perceived entrepreneurial behavior control berpengaruh signifikan positif terhadap entrepreneurial intentions. hal tersebut karena nilai T-statistics untuk kedua hipotesis tersebut < 1.96 .

\section{Hubungan antara Individual Skill terhadap Attitude toward Entrepreneurial Behavior}

Hasil pengujian hipotesis menunjukkan bahwa terdapat hubungan positif dan signifikan antara individual skill dan attitude toward entrepreneurial behavior. Hal tersebut menunjukkan bahwa hasil penelitian ini mendukung hasil dari penelitian sebelumnya. Pada penelitian sebelumnya disebutkan bahwa ketika seseorang memiliki kesadaran akan skill dan kompetensi yang dimilikinya, hal tersebut akan berpengaruh pada tingkat sejauh mana seseorang mengembangkan penilaian (menguntungkan atau tidak menguntungkan) terkait perilaku yang bersangkutan. Oleh karena itu, adanya kesadaran seseorang tentang kompetensi yang dimilikinya akan memberikan evaluasi yang lebih baik untuk fokus perilaku yang dituju, yang secara tidak langsung mendorong munculnya niat. Shapero dan Sokol (1982), serta Souitaris, Zerbinati, dan Al-Laham (2007), juga memperkuat hal tersebut, dimana individual skill berpengaruh secara langsung pada attitudes dan berpengaruh tidak langsung pada entrepreneurial intentions. Bila kemudian dikaitkan dengan hasil penelitian terkait deskripsi jawaban responden, terlihat pula bahwa responden penelitian ini merasa memiliki skill dan kompetensi yang baik untuk melakukan tindakan kewirausahaan, utamanya terkait leadership skill, managerial skill, dan kematangan mereka dalam melakukan tindakan kewirausahaan. 


\section{Hubungan antara Perceived Environmental Facility terhadap Perceived Entrepreneurial Behavior Control}

Hasil penelitian menunjukkan bahwa hubungan antara perceived environmental facility terhadap perceived entrepreneurial behavior control memiliki hasil yang positif namun tidak signifikan. Hasil ini tidak mendukung teori dari penelitian sebelumnya yang menyatakan bahwa dukungan lingkungan eksternal sangatlah penting untuk mendukung kegiatan kewirausahaan (Fini, Grimaldi, \& Sobrero, 2009). Ketika terdapat dukungan lingkungan baik dari dukungan pemerintah, status ekonomi, ketersediaan modal, infrastruktur, dukungan universitas, dan layanan dukungan kewirausahaan lainnya, hal tersebut akan mampu mendukung dan mempromosikan kegiatan kewirausahaan. Dengan adanya lingkungan yang mendukung, maka akan berpengaruh positif pada kendali seseorang untuk melaksanakan perilaku kewirausahaan, dan mempengaruhi rasa percaya diri mereka untuk berhasil ketika menerapkan perilaku kewirausahaan. Hasil penelitian ini tentu berbanding terbalik dengan pernyataan tersebut. Bila diperhatikan lebih lanjut dari hasil jawaban responden, responden memang merasa bahwa dukungan dari lingkungan kampus utamanya dari segi infrastruktur untuk penciptaan usaha baru sudah baik. Namun di sisi lain, responden merasa bahwa dukungan dari segi pemerintah terutama untuk akses bantuan finansial atau permodalan dan ketersediaan informasi serta kondisi ekonomi yang dirasa tidak memungkinkan untuk memulai bisnis menyebabkan kontrol terhadap perilaku kewirausahaan menjadi rendah. Hal inilah yang kemudian harus dibenahi bahwa tidak cukup hanya dukungan dari lembaga pendidikan (universitas), tetapi juga dukungan dan peran aktif dari pemerintah juga sangat dibutuhkan untuk mempermudah kaum muda dalam hal ini mahasiswa/i untuk memperoleh informasi dan bantuan permodalan agar mereka merasa semakin yakin dan percaya diri untuk melakukan perilaku kewirausahaan dan menumbuhkan niat mereka untuk berwirausaha.

\section{Hubungan antara Perceived Environmental Dynamism terhadap Perceived Entrepreneurial Behavior Control}

Hasil penelitian menunjukkan hubungan antara perceived environmental dynamism terhadap perceived entrepreneurial behavior control memiliki pengaruh positif dan signifikan. Hal ini menunjukkan bahwa hasil penelitian ini mendukung hasil penelitian sebelumnya. Adanya peluang akan mempengaruhi niat dan tindakan seseorang. Ketika jumlah peluang yang dirasakan seseorang semakin besar, maka semakin besar pula kontrol atas perilaku fokal (Ajzen, 1991). Keadaan lingkungan yang dinamis dan berubah-ubah juga memungkinkan individu untuk lebih memahami, menemukan, atau menciptakan peluang. Selain itu, lingkungan yang aktif dan heterogen akan mengasah perilaku inovatif, proaktif, dan keberanian individu untuk mengambil resiko. Responden penelitian ini juga memiliki persepsi yang sangat tinggi terhadap kondisi lingkungan yang dinamis dalam mengambil tindakan kewirausahaan. Mereka merasa bahwa dengan tingginya tingkat dinamisme pasar, buying habits konsumen serta tingkat kompetisi yang juga tinggi, mereka melihat peluang yang baik untuk memulai bisnis. 
2077 (online)

Volume 4, No. 2, Desember 2019

http://journal.undiknas.ac.id/index.php/manajemen

\section{Hubungan antara Attitudes toward Entrepreneurial Behavior terhadap Entrepreneurial Intentions}

Hasil penelitian menunjukkan bahwa hubungan antara attitudes toward entrepreneurial behavior terhadap entrepreneurial intentions memiliki pengaruh positif dan signifikan. Hal tersebut menunjukkan bahwa hasil penelitian ini mendukung teori dari penelitian sebelumnya. Eagly \& Chaiken (1993) menyatakan bahwa sikap (attitudes) adalah kecenderungan psikologis pihak tertentu yang memiliki sifat-sifat evaluatif, baik yang menguntungkan atau tidak, terhadap perilaku tertentu, yang meliputi aspek kognitif, aspek afektif, dan aspek konatif. Kemudian Ajzen dan Fishbein (1977) juga menyatakan bahwa sikap dan perilaku saling berhubungan. Perilaku secara sistematis didahului oleh keputusan untuk bertindak, dimana sikap berkontribusi untuk membentuk perilaku masa depan seperti yang telah direncanakan secara kognitif. Lebih lanjut lagi, Davidson dan Jaccard (1979) menunjukkan bahwa terdapat hubungan positif yang kuat antara niat dan perilaku. Bagozzi (1981) secara empiris menunjukkan bahwa sikap mempengaruhi perilaku melalui dampak adanya niat perilaku. Jika dilihat pula dari hasil jawaban dari responden penelitian, responden memiliki ekspektasi yang sangat tinggi terkait tindakannya untuk memulai bisnis dan mereka memiliki pandangan yang positif terkait perilaku yang direncanakan dalam hal entrepreneurship. Mereka merasa bahwa menguntungkan bagi mereka untuk mengambil sikap terhadap perilaku kewirausahaan terkait penyaluran kreativitas dan juga sisi ekonomis yang kemudian hal tersebut diterjemahkan ke dalam niat yang kuat untuk melaksanakan perilaku yang diinginkan, dalam hal ini entrepreneurship. Bila dirunut lebih jauh, hal ini tidak terlepas juga dari tingginya keyakinan responden terkait skill dan kompetensi yang dimilikinya yang juga membuat mereka memiliki pandangan yang positif terkait perilaku kewirausahaan yang kemudian menumbuhkan niat mereka untuk berwirausaha.

\section{Hubungan antara Subjective Norms terhadap Entrepreneurial Intentions}

Hasil penelitian menunjukkan bahwa hubungan antara subjective norms terhadap entrepreneurial intentions memiliki pengaruh positif dan signifikan. Hasil ini tidak sejalan dengan penelitian oleh Fini et al. (2012). Di sisi lain, hasil penelitian ini mendukung penelitian oleh Nilsson, Borgstede, \& Biel (2004) yang menegaskan bahwa subjective norms merupakan konstruk yang menjelaskan keyakinan seseorang yang merujuk pada pengaruh pihak lain dalam berperilaku dengan cara tertentu dan yang menjadi motivasi untuk memenuhi referensi tertentu. Dengan kata lain, subjective norms adalah kecenderungan seseorang untuk mempertimbangkan dan mengikuti pandangan, bimbingan, dan dorongan untuk berperilaku atau tidak berperilaku dari pihak lain baik itu dari individu maupun kelompok, seperti dari kerabat, teman, dan tokoh masyarakat, termasuk dalam entrepreneurial behavior. Bila dilihat dari hasil jawaban responden, terlihat bahwa dukungan baik dari pihak keluarga maupun lingkungan sosial responden sangat berperan terkait pembentukan niat untuk berwirausaha. Meskipun memang tidak semua responden memiliki latar belakang keluarga sebagai entrepreneur, hal tersebut tidak serta merta mengurangi niat responden untuk mengambil tindakan kewirausahaan. 
Volume 4, No. 2, Desember 2019

http://journal.undiknas.ac.id/index.php/manajemen

\section{Hubungan antara Perceived Entrepreneurial Behavior Control terhadap Entrepreneurial Intentions}

Hubungan antara perceived entrepreneurial behavior control terhadap entrepreneurial intentions memiliki hasil yang positif namun tidak signifikan. Behavioral control didasarkan pada seberapa jauh seseorang bersedia dan mampu mengendalikan perilakunya, sehingga kecenderungan perilakunya dapat diamati, apakah perilaku tersebut memberikan kemudahan atau kesulitan. Jika behavioral controlnya tinggi, maka hal tersebut akan memberikan kesempatan yang lebih baik dimana : individu tersebut akan lebih siap, lebih optimis, lebih mudah, dan mampu menguasai proses untuk memulai dan mengembangkan entrepreneurship dan begitu pula sebaliknya. Dilihat dari hasil penilitian ini menunjukkan bahwa penelitian ini berbanding terbalik dengan penelitian sebelumnya oleh Franke dan Luthje (2004) yang mengungkapkan bahwa niat seseorang untuk berwirausaha dipengaruhi langsung oleh persepsi terhadap peluang dan rintangan kewirausahaan. Secara khusus, semakin positif seseorang merasakan dukungan untuk kewirausahaan, semakin kuat niat kewirausahaan mereka. Hal yang kemudian menjadi rintangan yang dirasakan oleh responden adalah terkait faktor dukungan lingkungan yang ada utamanya terkait masalah finansial, akses informasi, dan kondisi ekonomi yang tidak memungkinkan untuk memulai bisnis. Meskipun di sisi lain, responden merasa bahwa faktor lingkungan yang dinamis dan tingginya peluang membuat mereka merasa mampu mampu menguasai proses untuk memulai dan mengembangkan entrepreneurship.

\section{SIMPULAN}

Berdasarkan hasil analisa data yang ada, maka dapat disimpulkan bahwa pada penelitian ini yang memiliki pengaruh positif signfikan adalah hubungan antara individual skill attitude towards entrepreneurial behavior, perceived environmental dynamism terhadap perceived entrepreneurial behavior control, attitude toward entrepreneurial behavior terhadap entrepreneurial intentions, dan Subjective norms terhadap entrepreneurial intentions. Sementara itu, hubungan perceived entrepreneurial facility terhadap perceived entrepreneurial behavior control dan perceived entrepreneurial behavior control terhadap entrepreneurial intentions.

Dilihat dari penelitian ini, dukungan pemerintah sangatlah penting untuk meningkatkan niat untuk berwirausaha bagi kalangan muda. Namun yang perlu diperhatikan lagi adalah bagaimana pemerintah mampu memberikan bantuan, baik itu kemudahan informasi, administrasi, dan pemberian bantuan modal bagi kalangan muda yang ingin berwirausaha. Sementara itu lembaga pendidikan (universitas) sebaiknya lebih meningkatkan lagi kualitas program-program dan dukungan baik itu secara akademis maupun infrastruktur pendukung bagi mahasiswa/l yang memiliki minat tinggi untuk berwirausaha.

Kecilnya populasi dalam penelitian ini menjadi salah satu kendala sehingga sulit untuk mengeneralisasikan dan kurang menggambarkan keadaan sesungguhnya yang terjadi. Yang kemudian juga dapat dikembangkan lagi pada penelitian berikutnya adalah para akademisi dapat membandingkan lebih konkret lagi terkait pembentukan niat untuk bewirausaha di kalangan muda, yang cakupannya lebih luas lagi dari penelitian ini seperti dengan melihat latar belakang 
Volume 4, No. 2, Desember 2019

http://journal.undiknas.ac.id/index.php/manajemen

budaya yang berbeda dan sebagainya sehingga akan lebih menggambarkan dengan lebih jelas lagi terkait pembentukan niat untuk berwirausaha.

\section{REFERENSI}

Ajzen, Icek 1988. Attitudes, Personality, and Behavior. Chicago, Illinois: Dorsey Press.

Ajzen, I. 1991. The Theory of Planned Behavior. Organizational Behavior and Human Decision Processes.

Ajzen, I. 2002. Perceived Behavioral Control, Self-efficacy, Locus of Control, and The Theory of Planned Behavior. Journal of Applied Social Psychology, 32(4), 665-683.

Ajzen, I. 2005. Attitudes, Personality, and Behavior 2nd Edition. Open University Press (McGraw-Hill), England

Ajzen, I. and Fishbein, M. 1977. Attitude-behavior Relations: A Theoretical Analysis and Review of Empirical Research. Psychological Bulletin, Vol. 84 No. 5, pp. 888-918.

Ajzen, I. \& Fishbein, M. 1980. UnderstandingAattitudes and Predicting Social Behavior. Englewood Cliffs, NJ: Prentice Hall.

Algifari. 2003. Statistika Induktif untuk Ekonomi dan Bisnis. AM YKPN. Yogyakarta.

Arikunto, Suharsimi. 2002. Prosedur Penelitian IImiah Suatu Pendekatan Praktis. Jakarta : Rineka Cipta

Armitage , C. J., \& Conner, M. 2001. Efficacy of The Theory of Planned Behavior: A Meta Analytic Review. British Journal of Social Psychology, 40, 471-499.

Bagozzi, R.P. 1981. An Examination of The Validity of Two Models of Attitude. Multivariate Behavioral Research, Vol. 36 No. 3, pp. 323-59.

Bird, B. J., \& West, G. P. 1997. Time and Entrepreneurship. Entrepreneurship Theory and Practice, 22: 5-9.

Bird, B. 1988. Implementing Entrepreneurial Idea: The Case for Intention. Academy of Management Review.

Beck, T., Demirgüç-Kunt, A., \& Maksimovic, V. 2005. Financial and Legal Constraints to Firm Growth: Does Size Matter? Journal of Finance, 60(1), 137-151.

Basu, A., \& Virick, M. 2008. Assessing Entrepreneurial Intentions Amongst Students: A Comparative Study.

Baum, R.J., Locke, E., \& Smith, K.G. 2001. A Multidimensional Model of Venture Growth. Academy of Management Journal, 44(2), 292-303.

Barringer, B. R., \& Ireland, R. D. 2010. Entrepreneurship: Successfully Launching New Ventures (3rd ed.). New Jersey: Pearson.

Davidsson, Per. (1995). Determinants of Entrepreneurial Intentions.

Davidson, A.R. and Jaccard, J.J. 1979. Variables that Moderate The AttitudeBehavior Relation: Results of A Longitudinal Survey. Journal of Personality and Social Psychology, Vol. 37 No. 1, pp. 1364-76.

Covin, J.G. \& Slevin, D.P. 1989. Strategic Management of Small Firms in Hostile and Benign Environments. Strategic Management Journal, 10, 75-87.

Chin, W. W. and T. Frye. 1996. PLS Graph. Calgary, Canada : Soft Modelling Inc 
2077 (online)

Volume 4, No. 2, Desember 2019

http://journal.undiknas.ac.id/index.php/manajemen

Brannback, M., Krueger, N., Carsrud, A. and Elfving, J. 2007. Trying to be an Entrepreneur? A Goal-specific Challenge to The Intentions Model. Babson Conference Entrepreneurship Research, Madrid, June 7-9.

Fini, R., Grimaldi, R., \& Sobrero, M. 2009. Factors Fostering Academics to Start Up New Ventures: An Assessment of Italian Founders' Incentives. The Journal of Technology Transfer, 34, 380-402.

Fini, R., Grimaldi, R., Marzocchi, G.L., \& Sobrero, M. 2012. The Determinants of Corporate Entrepreneurial Intention Within Small and Newly Established Firms. Entrepreneurship Theory and Practice.

Fishbein, M, \& Ajzen, I. 1975. Belief, Attitude, Intention and Behavior: An Introductin to Theory and Research. Addison-Wesley Publishing Company inc. Menlo Park, California.

Foo, M.D., Wong, P.K., \& Ong, A. 2005. Do Others Think You Have a Viable Business Idea? Team Diversity and Judges' Evaluation of Ideas in a Business Plan Competition. Journal of Business Venturing, 20(3), 385402.

Franke, N. and Luthje, C. 2004. Entrepreneurial Intentions of Business Students: A Benchmarking Study. International Journal of Innovation and Technology Management, 1(3), 269-88.

Eagly, A. H., \& Chaiken, S. 1993. The Psychology of Attitudes. Fort Worth. Harcourt Brace Javanovich.

Dell, M. S. 2008. An Investigation of Undergraduate Student Self-employment Intention and The Impact of Entrepreneurship Education and Previous Entrepreneurial Experience. Doctor of Philosophy, School of Business University The Australia.

Dohse, D., \& Walter, S. G. 2010. The Role of Entrepreneurship Education and Regional Context in Forming Entrepreneurial Intentions. Working Paper present at Document de treball de I"IEB 2010/18

Janssen, Frank et al. 2012. Entrepreneurial Perceptions and Intentions: The Role of Gender and Culture. Entrepreneurship Theory and Practice : Baylor University.

Jogiyanto. 2011. Konsep dan Aplikasi Structural Equation Modeling Berbasis Varian Dalam Penelitian Bisnis. Yogyakarta : UPP STIM YKPN.

Gurbuz, G. \& Aykol, S. 2008. Entrepreneurial Intentions of Young Educated Public in Turkey. Journal of Global Strategic Management, 4(1): 47-56.

Hair, J. F. J., Lack, W. C., Babin, B. J., Anderson, R. E., \& Tatham, R. L. 2008. Multivariate Data Analysis (6 ed.). New York: Pearson Prentice Hall.

Gasse, Y. 1985. A Strategy for The Promotion and Identification of Potential Entrepreneurs at The Secondary Level. Frontiers of Entrepreneurship Research 1985 (pp. 538-559). Wellesley, MA: Babson College Center for Entrepreneurial Studies.

Gay, L. R. and P. L. Diehl. 1992. Research Methods for Business and Management,.USA : Macmillan.

Ghozali, Imam. 2008. "Structural Equation Modelling : Metode Alternatif dengan Partial Least Square (PLS)", Semarang : Badan Penerbit UNDIP.

Krueger, N. F. J., Reilly, M. D., \& Carsrud, A. L. 2000. Competing Models of Entrepreneurial Intentions. Journal of Business Venturing, 15(5), 411-432.

Leong, C. K. 2008. Entrepreneurial Intention: An Empirical Study Among Open University Malaysia Students. Dessertation, Open University Malaysia Center for Graduate Studies. 
2077 (online)

Volume 4, No. 2, Desember 2019

http://journal.undiknas.ac.id/index.php/manajemen

Lerner, J. 1999. The Government as Venture Capitalist: The Long-run Impact of The SBIR Program. Journal of Business, 72(3), 285-318.

Leroy, H., Maes, J., Sels, L., Debrulle, J., Meuleman, M. and Leuven, V. 2009. Gender Effects on Entrepreneurial Intentions: A TPB Multigroup Analysis at Factor and Indicator Level. paper presented at the Academy of Management Annual Meeting, Chicago, IL, August 7-11.

Levin, R. I., and Rubin D. S. 1998. Statistics for Management. Englewood Cliffs. New Jersey : Prenntice Hall.

Jonathan, Sarwono. 2006. Metode Penelitian Kuantitatif dan Kualitatif. Yogyakarta: Graha IImu

Kolvereid, L. 1996. Prediction of Employment Status Choice Intentions. Entrepreneurship Theory and Practice Vol. 21 No. 1, pp. 47-57.

Meeks, M. 2009. Antecedents to The Entrepreneurial Decision: An Empirical Analysis of Three Predictive Models. PhD Thesis, Available at: http://ssrn.com/abstract $=1345480$

Liñán, F., \& Chen, Y. W. 2009. Development and Cross-cultural Application of $A$ Specific Instrument to Measure Entrepreneurial Intentions. Entrepreneurship Theory \& Practice, 33(3), 593-617.

Linan, F., J. C. Rodriguez-Cohard., \& J. M. Rueda-Cantuche. 2005. Factors Effecting Entrepreneurial Intention Levels. 45th Congress of the European Regional Science Association, Amsterdam.

Locke, E.A. 2000. Motivation, Cognition and Action: An Analysis of Studies of Task Goals and Knowledge. Applied Psychology: An International Review, 49, 408-429.

Lüthje, C. \& Franke, N. 2003. The "Making" of an Entrepreneur : Testing a Model of Entrepreneurial Intentions among Engineering Students at MIT. Research and Development Management, 3(2), 135-147.

Meyers, S. \& Marquis, D.G. 1969. Successful industrial innovations. NSF 6917.Washington, DC: National Science Foundation.

Mian, S.A. 1996. Assessing Value-added Contributions of University Technology Business Incubators to Tenant Firms. Research Policy, 25(3), 325-335.

Mian, S.A. 1997. Assessing and Managing The University Technology Business Incubator: An Integrative Framework. Journal of Business Venturing, 12, 251-285.

Miller, S. \& Friesen, P. 1982. Innovation in Conservative and Entrepreneurial Firms: Two Models of Strategic Momentum. Strategic Management Journal, 3, 1-25.

Morris, M., \& Lewis, P. 1995. The Determinants of Entrepreneurial Activity. European Journal of Marketing, 29(7): 31-48.

Morris, M. H. \& Jones, F. F. (1999). Entrepreneurship in Established Organizations: The Case of the Public Sector. Entrepreneurship Theory and Practice, 24(1), 71-91.

Nawangpalupi. C.B., Pawitan, G., Gunawan, A., Widyarini, M., Iskandarsjah, T. 2014. Global Entrepreneurship Monitor 2013 Indonesia Report. Bandung: Universitas Katolik Parahyangan.

Nilsson, A., Borgstede, C. V., \& Biel, A. 2004. Willengness to Accept Climate Change Strategy: The Effect Values and Norms. Journal of Environmental Psychology, 24, 3, 267-277.

Niosi, J. \& Bas, T.G. 2001. The Competencies of Regions: Canada's Clusters in Biotechnology. Small Business Economics, 17(1-2), 31-42. 
Volume 4, No. 2, Desember 2019

http://journal.undiknas.ac.id/index.php/manajemen

Nosek, B. A., Banaji, M. R., \& Greenwald, A. G. 2002. Math = Male, Me = Female, therefore Math $\neq$ Me. Journal of Personality and Social Psychology, 83, 4459.

OECD .2011. Obstacles to Entrepreneurship by Gender. in Entrepreneurship at a Glance. OECD Publishing.

Ooi, Y, K., Selvarajah, C., \& Meyer, D. 2011. Inclination towards Entrepreneurship among University Students: An Empirical Study of Malaysian University Students. International Journal of Business and Social Social Science, 2(4), 206-220.

Ranto, Basuki. 2007. Manajemen Usahawan Indonesia No. 10/TH.XXXVI Oktober. Bagian Publikasi Lembaga Management FEUI. Jakarta. Hal.5.

Roberts, E.B. 1991. Entrepreneurs in High Technology: Lesson from MIT and Beyond. New York: Oxford University Press.

Sugiyono, Dr. 2010. Metode Penelitian Kuantitatif, Kualitatif, dan R\&D. Bandung : Alfabeta.

Tenenhaus, M., Vinzia, V., Chatelin, Y.-M., \& Lauro, C. 2005. PLS Path Modeling Computational Statistics \& Data Analysis, 48; 159 - 205.

Stevenson, H. H. and J. C. Jarillo 1990. A Paradigm of Entrepreneurship: Entrepreneurial Management', Strategic Management Journal, 11, pp. 1727.

Shapero, Albert, \& Sokol, L. 1982. The Social Dimensions of Entrepreneurship. In C. Kent, D. L. Sexton, \& K. Vesper (Eds.), The encyclopedia of entrepreneurship (pp. 72-90). Englewood Cliffs: Prentice-Hall.

Singarimbun, Masri and Sofyan Efendi. 1995. Metode Penelitian Survey. Jakarta : LP3ES

Shane, S., Locke, E.A., \& Collins, C.J. 2003. Entrepreneurial Motivation. Human Resource Management Review, 13(2), 257-279.

Souitaris, V., Zerbinati, S., \& Al-Laham, A. 2007. Do Entrepreneurship Programmes Raise Entrepreneurial Intention of Science and Engineering Students? The Effect of Learning, Inspiration and Resources. Journal of Business Venturing, 22, 566-591.

Rhodes, R,E., \& Courneya, K. S. 2003. Investigating Multiple Components of Attitude, Subjective norms, Perceived Control: An Examination The Theory of Planned Behavior in The Exercise Domain. British journal of social psychology, 23, 42 ,129-146.

Riyanti, Benedicta Prihatin Dwi. (2003). Kewirausahaan Dari Sudut Pandang. Psikologi Kepribadian. Jakarta : Grasindo

Sakarya, S., Eckman, M., \& Hyllegard, K.H. 2007. Market Selection for International Expansion: Assessing Opportunities in Emerging Markets. International Marketing Review, 24(2), 208-238.

Van Gelderen, M., Brand, M., van Praag, M., Bodewes, W., Poutsma, E., \& van Gils, A. 2008. Explaining Entrepreneurial Intentions by Means of The Theory of Planned Behaviour. Career Development International, 13(6), 538-559.

Wiklund, J. \& Shepherd, D. 2003. Knowledge-based Resources, Entrepreneurial Orientation, and The Performance of Small and Medium-sized Businesses. Strategic Management Journal, 24, 1307-1314.

Wijaya, Tony. 2007. Hubungan Adversity Intelligence dengan Intensi Berwirausaha. Jurnal Manajemen dan Kewirausahaan.Vol.9 No.2 September:117-127 
Zain, Rozihana Shekh et al. 2009. Entrepreneurial Intention among Malaysian Undergraduates. International Journal of Business and Management Vol. 4, No. 10. October 2009.

Zikmund, William G. 1997. "Business Research Methods". USA: Dryden Press. Hill, New York.

http://hatta-rajasa.info/read/2501/memajukan-bangsa-lewat-enterpreneurship diakses pada 17 Desember pukul 2014 pukul 09.15 WIB

http://www.tempo.co/read/news/2014/03/25/089565338/Modal-Wirausaha-KaumMuda-Dikucurkan-Usai-Pemilu diakses pada 17 Desember pukul 2014 pukul 09.15 WIB

http://www.depkop.go.id/index.php?option=com content\&view=article\&id=1371:b agi-wirausaha-pemula-bersiaplah-diguyur-dana-segar-rp25-

juta\&catid $=50$ :bind-berita\&ltemid=97 diakses pada 17 Desember pukul 2014 pukul 09.15 WIB

http://www.antaranews.com/berita/484788/pemerintah-luncurkan-paketkebijakan-pengembangan-wirausaha diakses pada 17 Desember pukul 2014 pukul 09.15 WIB 